\title{
Students' Mathematical Critical Thinking Ability in Solving The Application of First-Order Differential Equations
}

\author{
Arfatin Nurrahmah ${ }^{1}$, Stevanus Budi Waluya ${ }^{2}$, Tri Sri Noor Asih ${ }^{3}$, \\ Nurina Kurniasari Rahmawati ${ }^{4}$, Arie Purwa Kusuma ${ }^{5}$ \\ $\left\{\right.$ arfatinnurrahmah@students.unnes.ac.id ${ }^{1}$, s.b.waluya@mail.unnes.ac.id ${ }^{2}$, \\ inung.mat@mail.unnes.ac.id ${ }^{3}$, nurinakr@students.unnes.ac.id $\left.{ }^{4}\right\}$ \\ Doctoral Program Mathematics Education, Universitas Negeri Semarang, Sekaran, Gunung Pati, \\ Semarang City, Central Java ${ }^{1,4,5}$, Universitas Negeri Semarang, Sekaran, Gunung Pati, Semarang City, \\ Central Java ${ }^{2,3}$
}

\begin{abstract}
Many mathematical problems of natural symptoms whose mathematical models can be formulated in the form of differential equations. Because the problem is complex, students need to develop their thinking skills, one of which is critical thinking. This study aims to describe students' mathematical critical thinking ability in solving the problem of the application of first-order differential equations. The method used in this study is descriptive qualitative. The subject of this study was a 6th-semester student of Indraprasta PGRI Indraprastha, with as many as three people. The selection of subjects is donetopicsosive sampling, based on the results of pretests. The instruments used are critical thinking skills tests (pretest and posttest questions), interview guidelines, and researchers. Data analysis techniques are carried out through data reduction, presentation of data, and verification. The results showed that there were student's critical thinking ability in solving problems of applying first-order differential equations, especially in subjects with high (L6) and moderate pretest (M9) results that met all indicators. However, issues with low pretest results (L2), from the three questions given, could only work on one question and did not fulfill the critical thinking indicators in the other two questions.
\end{abstract}

Keywords: Mathematical Critical Thinking, Application of First-Order Differential Equations

\section{Introduction}

Differential equations play an essential role in mathematics [1] to model different reality situation reality situations, allowing us to understand the characteristics of a particular phenomenon by analyzing its mathematical properties [2]. Differential equations are one of the courses that students of mathematics education must study. Especially in the mathematics education study program of Indraprastha PGRI University, differential equation courses are divided into primary or ordinary differential equations and advanced differential equations, where ordinary differential equations only focus on first-order.

A first-order differential equation is the most straightforward differential equation because it contains only the first derivative of an unknown function. Although simple in structure, many phenomena in life can be modeled as differential equations of order one. For decades, much 
scientific knowledge of physics and engineering has been revealed through differential equations [3]. Application of first-order differential equations in other fields, among others decay of radioactive substances, growth, and shrinkage of population, heating, cooling, evaporation, financial development, stock price dynamics, drug dose regulation, cell division, and so on [4].

According to Widowati and Sutimin, people often need a mathematical model of the problem at hand about natural symptoms or phenomena. Many mathematical problems of natural symptoms whose mathematical models can be formulated in first-order differential equations. Furthermore, from the mathematical model obtained, this solution is searched by the appropriate method. This mathematical modeling is used to represent and explain physical systems or problems in the real world and mathematical statements to understand these realworld problems more precisely [5].

The problems in the learning of differential equations today are only focused on solving ordinary differential equations using algebraic or analytical methods. The solution is like this that students can find explicit or implicit expressions for unknown functions. These methods are characterized by algorithmic, procedural, symbolic, and particularly related properties of certain types of differential equations [6]. For example, determine the general solution of differential equations of separate variables, homogeneous, nonhomogeneous, exact and non-exact, linear order one, and Bernoulli. A literature survey on the teaching and learning of differential equations shows that for students, the relationship between differential equations, their solutions, and what each might represent is physical, meaningless. One reason is that differential equation themselves are complex, built on calculus, algebra, fundamental analysis, etc [7].

Another problem is that most of the teaching materials taught in differential equation materials today are widely circulated in abstract form. Students learn with examples of issues and formulas that have been provided and are trained to be able to solve problems without knowing their usefulness [8]. Learning like this makes students less constructive understanding of the underlying equation and appreciates what it means to be the solution of the equation [9]. Students have difficulty when studying ordinary differential equations and their application to real physical scenarios [10]. Thus, in the study of differential equations, it is essential to include fairly extensive material about the application and modeling of mathematics. This needs to be done to reassure students that mathematical modeling often leads to differential equations, and differential equations are part of problem investigations in various other areas. Because real-life problems are complex, students must develop their thinking skills [11]; one of them is thinking critically.

Critical thinking is one of the essential abilities in the $21 \mathrm{st}$ century [12]. Critical thinking is often described as a cognitive process consisting of several sub-skills (e.g., analysis, evaluation, and inference) that, when used appropriately, can produce logical conclusions for an argument or solution to a problem [13]. Critical thinking is necessary for solving math problems because critical thinking provides the right direction in thinking and working and helps find appropriate interrelationships of factors [14]. Another opinion states that critical thinking involves complex intellectual activity that emphasizes the following capabilities: problem formulation, problem reformulation, evaluation, the sensitivity of problems [15]. Six critical thinking abilities arise in the learning process, namely, (1) Interpretation is to understand and express the meaning of various experiences, real situations; (2) Analysis means the identification of the relationship between statements, questions, concepts, or other forms of representation; (3) Inference means identifying the elements necessary to draw reasonable conclusions; (4) Evaluation means to judge statements or other representations of oneself or others; (5) Explanation is the skill of determining and sharing reasons directly and logically 
based on the data obtained, (6) Self-regulation is a skill to monitor a person's cognitive activity, the elements used in problem-solving mainly to apply skills in analyzing and evaluating [16]. Critical thinking should include several characteristics, such as analyzing, synthesizing, introducing and solving problems, concluding, and assessing [17].

A previous study conducted by [18] modified indicators of critical thinking ability according to Facione and Angelo to analyze and categorize the essential thinking abilities. These critical indicators in thinking include: interpreting problems, researching solutions, implementing solutions, evaluating solutions, and concluding the results obtained with supporting evidence. These indicators were further used in this study. Based on the description, this study aims to describe students' mathematical critical thinking ability in solving the problem of first-order differential equation application.

\section{Research Methods}

The method used in this study is descriptive qualitative. The subjects or participants of this study were students of semester 6 of Indraprastha PGRI University, as many as three people who attended ordinary differential equation courses. Subject retrieval is done by purposive sampling. After students were given a pretest, the subject's answers were analyzed based on indicators of critical thinking ability. Then a semistructured interview was conducted on the selected subject. Interviews via Google Meet are recorded as research documentation for data analysis purposes. This study uses various instruments, i.e., critical thinking skills tests (pretest and posttest), interview guidelines, and researchers as crucial instruments. The mathematical essential thinking ability for pretest and posttest used has been validated to be ready for use in research. Data analysis techniques are carried out through data reduction, continued presentation of data, and withdrawal of conclusions and verification. Then, the data obtained is tested for validity using the triangulation method by comparing test result data, interviews to subjects, and observation results during the learning process. For the technique of grouping students' critical thinking abilities, researchers used the rules of grouping over three ranks using mean formulas and deviation standards. Pretest data was analyzed before the study, which aims to group students into three categories, i.e., high, moderate, and low, to select research subjects. The results are presented in the following table.

Table 1. Pretest Result

\begin{tabular}{ccccc}
\hline Category & $\begin{array}{c}\text { High } \\
(\text { percentage } \%)\end{array}$ & $\begin{array}{c}\text { Moderate } \\
(\text { percentage } \%)\end{array}$ & $\begin{array}{c}\text { Low } \\
(\text { percentage } \%)\end{array}$ & Totality \\
\hline Sum & $6(22,22 \%)$ & $15(55,56 \%)$ & $6(22,22 \%)$ & 27 \\
\hline
\end{tabular}

Based on table 1, the distribution of student pretest results is at most in the moderate category. While the number of students in the high and low classes balanced by a percentage of $22.22 \%$. After dividing students into three categories based on pretest results, the researchers then took posttest data on mathematical critical thinking ability by applying differential equations in order one. The essential thinking ability of the research subjects was analyzed based on five indicators, namely: a) interpreting the problem, b) analyzing the solution, c) applying the solution, d) evaluating the solution, and e) concluding the results. The application of differential equations given in this study consists of three questions concerning population 
growth, Newton's Laws of cooling, and the decay of radioactive substances. The question was tested in the form of a description [19]. The given issue requires students to conduct investigations, seek ideas in interpreting information, analyzing information, and evaluating evidence and arguments.

\section{Results and Discussion}

\subsection{Result}

The distribution of students' critical thinking ability based on pretest and posttest results is presented in figure 1 below.

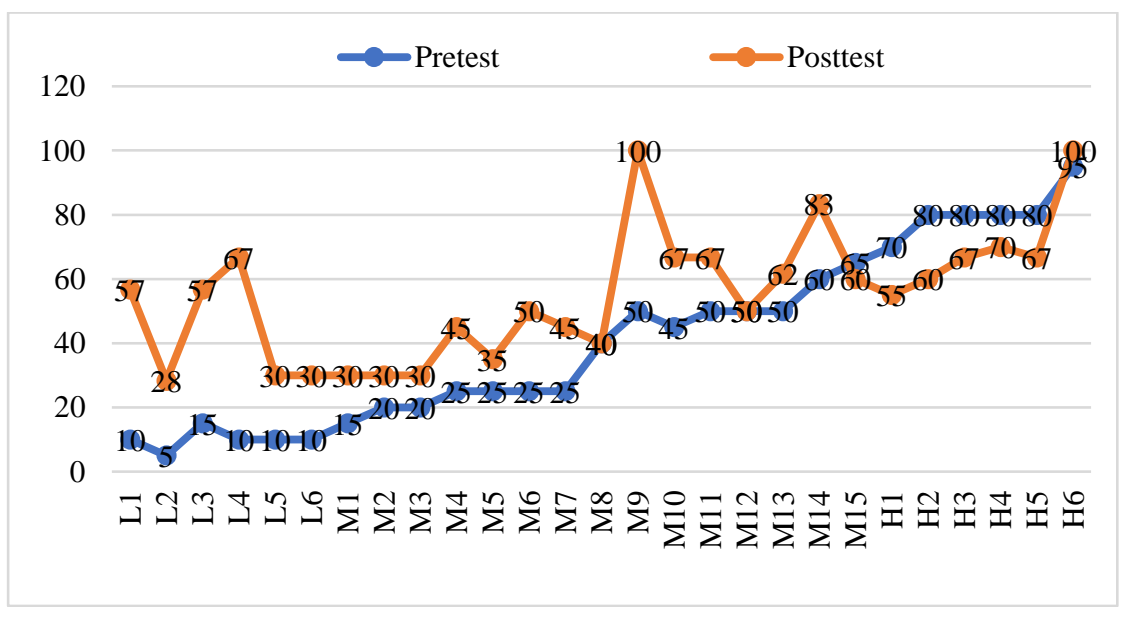

Fig. 1. Distribution of students' mathematical critical thinking ability

Figure 1 shows the spread of students' critical thinking ability based on pretest and posttest in solving first-order differential application problems. As seen in Figure 1, most of the increase in the posttest, except M15, H1, H2, H3, H4, and H5, decreases. When viewed from the average, there is an increase in the ability to think critically of students, although not significantly. Based on these results, an in-depth analysis of the research subjects was conducted. The selection of subjects is taken based on specific criteria, namely: 1) students with pretest results in the high category and posttest results are also high, called subject 1 (H6);2) students whose pretest results on moderate category, and high posttest results, are called subject 2 (M9); 3) students whose pretest results are low and posttest results are low, are called subject 3 (L2).

\section{H6 Data Analysis}

Based on the results of critical thinking ability tests, H6 can solve all three problems of the application of first-order differential equations appropriately. For question number 2, H6 can print information based on the issue in the indicator interpreting the problem. However, in writing the population number, H6 does not use variables instead of an unknown value. For example, to state the population at the time of 60 years, H6 writes with "3 times". From the interview results, $\mathrm{H} 6$ stated that he understood better if he wrote what was known and asked using the phrase "multiply." After interpreting the problem, H6 analyzes the solution by 
connecting information and concepts and writing down a mathematical model based on the given situation. H6 illustrates population growth problems through mathematical models $\frac{d x}{d t}=$ $k t$. Based on the mathematical model, $\mathrm{H} 6$ applies solutions and uses acquired strategies to solve problems. H6 interjects first by separating each variable so that a standard solution is obtained. A unique key is obtained by $\mathrm{H} 6$ after substituted known values to get $\mathrm{k}$ (comparable constants). Using the previously provided information, $\mathrm{H} 6$ re-examines each completion step and reviews the identified knowledge, resulting in a result of $\mathrm{t} \approx 87.9$ years. The last step is, $\mathrm{H} 6$ concludes the answer given is the time it takes for the population in the city to be five times that of about 88 years.

A semistructured interview via Google Meet was then conducted to H6. From the interview results with $\mathrm{H} 6$ related to the application of first-order differential equations, $\mathrm{H} 6$ stated that at first did not like to work on the problem in the form of a story because of difficulty understanding the given issues. However, after knowing the usefulness of the application material of the first-order equation in real life, he became more challenged trying to analyze the problem first and determine how it works to produce the correct conclusion.

Based on the results of answers and interviews, H6 experienced an increase in critical thinking ability, although not significant. H6 may write down what is known and asked about this matter wholly and appropriately; can write down the mathematical model of the given problem correctly and provide a correct and complete explanation; can use the right strategy in solving problems, complete and accurate in making calculations or explanations; can reexamine each step of the settlement and review the clearly and appropriately identified information; and can make conclusions properly, by the context of the problem and complete. Thus, H6 meets all indicators of critical thinking ability in solving the problem of first-order differential equation application.

\section{M9 Data Analysis}

Figure 1 suggests that the M9 is in the moderate category from the pretest results, and the posttest results of its critical thinking ability indicate a high class. Based on the posttest results, M9 was able to answer all three questions of applying for the order one differential equation correctly. On the indicator interpreting the problem, M9 can understand and write down the information obtained from the situation. Unlike H6, M9 assumes an unknown value with variables. M9 For example, in question number 2, to state the initial number of unknown populations with variable a. So to say the people at the time of 60 years to triple that is $3 \mathrm{a}$, and to state, the population illustrates the problem of population growth through mathematical models. Furthermore, M9 implements solutions and uses acquired strategies to solve problems by finding standard solutions and specific solutions. Based on this particular solution, M9 uses the information it has obtained to find the time it takes for the population to be five times. M9 rechecks each completion step and reviews the identified knowledge, thus accepting $t \approx 87,9$ years. In concluding the answer given, M9 wrote, "So, the time it takes to achieve five times the population increase is 87.9 years".

Although M9 based on pretest results is moderate, M9 gets excellent results on posttest results. This suggests an improvement in M9's critical thinking ability after obtaining the differential equation application material. Semistructured interviews were conducted to determine M9's responses to the application of the first-order differential equation. M9 says that studying the application material of differential equations requires extra understanding to understand what is known and asked in the question and how to model a real problem. After studying this material, M9 became more aware of the benefits of applying derivatives and integrals in various fields other than mathematics, such as physics and biology. By knowing the 
material of differential equations is very applicative, M9 becomes more motivated in learning differential equations.

Based on test and interview results, M9 experienced a significant improvement in critical thinking skills. M9 may write down what is known and asked about this matter wholly and appropriately; can write down the mathematical model of the given problem correctly and provide a correct and complete explanation; can use the right strategy in solving problems, complete and accurate in making calculations or explanations; can re-examine each step of the settlement and review the clearly and appropriately identified information, and make precise conclusions and by the context of the problem. Thus, from the five indicators of critical thinking ability in solving the application of first-order differential equations, M9 can meet all these indicators.

\section{L2 Data Analysis}

L2 is a subject where pretest results are in a low category. At the time of the pretest, L2 could not answer at all the given problem. Although there is an improvement in posttest results, the ability to think critically of L2 is still in the low category. Of the three differential equation application questions given, L2 can only answer one question about Newton's Laws of cooling, where the problem is given in determining the temperature of coffee at a given time. L2 can do the problem because it is similar to the examples and exercises studied. As for other issues concerning population growth that are not answered correctly by L2, L2 does not write down the answers about the decay of radioactive substances. On population growth, L2 cannot interpret the sentence in the question, so it does not write down what is known and asked. In the following indicator, which analyzes the problem's solution, L2 cannot find a suitable mathematical model. L2 thinks out of context and uses the simplest way to answer the population in a given year, i.e., using a concept of comparative worth. With this concept, L2 gets the answer to the people to be five times after 100 years.

From the interview, L2 stated that it is not familiar with population growth because it is different from the examples of questions and exercises that have been done. The question is not given information on the number of inhabitants in a given year, only written with "multiply." While in the exercises that have been done in L2, clearly written information on the number of residents in the year. The same is the case with the decay of radioactive substances. The question does not write down information about the number of radioactive substances in a given year. So, L2 doesn't understand how to solve problems like this. This indicates that L2 is not yet used to working on different questions with examples. The lack of precise L2 in interpreting the given situation and the lack of precision in describing the problem through mathematical models resulted in L2 not being able to use strategies to solve problems and provide conclusions.

Based on the results of tests and interviews, although L2 can solve problems about Newton's Laws of cooling when given a compound that has low critical thinking ability. This is because, on other issues presented, namely about population growth and decay of radioactive substances, L2 cannot write down what is known and what is asked; improper writing of mathematical models of a given problem; using incorrect and incomplete strategies in solving problems; not review the identified information, and make erroneous conclusions that do not fit the context of the problem. Thus, L2 has not met all indicators of critical thinking ability in solving the application of first-order differential equations. 


\subsection{Discussion}

Based on the results of research on the subjects (H6, M9, and L2), there was an improvement in the critical thinking ability of each subject after being given the material application of differential equations order one. This can be seen from the results of the pretest and posttest subjects (see figure 1). Of the three subjects analyzed, the most significant improvement was M9. H6 and M9 have high critical thinking ability to solve differential equation application order problems, interpret issues, research, apply and analyze solutions, and conclude results correctly.

From the interview results, before trying to work on the given question, H6 and M9 try to understand the meaning of the sentence first by understanding word by word. H6 said that understanding the given problem takes a bit longer. Similar to H6, M9 tries to interpret the question to find out what information can be known and asked in the question carefully. The results of previous research stated that a person who has a high ability to think critically would be more thorough and careful to solve problems [20]. When someone thinks critically about solving a problem in mathematics, they will make a reasoned decision or judgment about what to do and think about. In other words, the student considers the criteria or basis for a wise decision and not just guesses or applies the rule without assessing its relevance.

Another factor that is considered to affect students' critical thinking ability is that if students realize the usefulness and benefits of studying differential equation applications, then those students will get good results. Based on interviews with H6 and M9, they became more motivated and interested in learning differential equations after learning their usefulness and benefits. The results of previous research stated that several factors affect students' ability to solve differential equation problems at the university level. The four elements include epistemological math problem-solving beliefs, beliefs about the usefulness of mathematics, selflearning strategies, and goal orientation, which have great potential to improve the problem skills of differential equations. One factor, namely beliefs about the usefulness of mathematics, is considered to positively influence this study, such as the results of analysis of H6 and M9 subjects.

Furthermore, in critical thinking, indicators interpret the problem and solve the real problems given play an essential role. When a person misinterprets the meaning of a given problem, then he will find it challenging to find the right solution. As L2, when he mistook the purpose of the given problem, L2 had difficulty predicting the relationship or explaining the information in question. This is according to the study results, which states that students' interpretation and understanding of the context of a problem is the key to successfully solving problems [21].

The application of first-order differential equations is new for students. Students who were only used to working on routine problems, such as finding standard solutions or unique solutions to differential equations, should represent and explain issues in the real world through mathematical modeling. Mathematical modeling itself is essential to study in differential equation courses. Mathematical modeling often leads to differential equations, and differential equations are part of problem investigations in various other fields. Ideally, modeling helps students express and socialize their thoughts, visualize and test the components of their theory, and make the material more interesting. Therefore, teachers need to introduce modeling in math learning, especially in differential equation courses. Previous research has shown that mathematical modeling can help develop competencies in different math classes [11].

The results of other studies state that modeling in mathematics learning can develop students' skills [22]; other studies say that modeling in mathematical knowledge can be like critical thinking ability by the opinion that critical thinking is a skill that can be developed [23]. 
In addition to the importance of mathematical modeling in the learning of differential equations, students need to be used to working on questions that require more complex understanding and analysis. Developing students' critical thinking skills is to create a learning atmosphere that can encourage students to be actively involved in learning; students do more activities such as open dialogue than just listening [24].

\section{Conclusion}

Many mathematical problems are from natural phenomena whose mathematical models can be formulated in the form of first-order differential equations. Because problems in life are complex, students must develop critical thinking skills. To describe students' mathematical critical thinking ability in solving first-order differential equations application problems, an indepth analysis was carried out on three research subjects (H6, M9, and L2). Where the results obtained, from the three subjects, H6 and M9 can meet all indicators of critical thinking skills in solving first-order differential equations application problems. While L2 cannot meet the critical thinking ability indicator. This study has not highlighted further the role of mathematical modeling on student learning outcomes and the use of applications in solving differential equation problems. So, suggestions for further research to better highlight how modeling in mathematics learning can develop a variety of student skills, critical thinking skills; and highlights about using computer applications such as GeoGebra, maple, etc., improving students' ability in differential equation courses.

\section{References}

[1] S. Arslan, "Do students really understand what an ordinary differential equation is?," Int. J. Math. Educ. Sci. Technol., vol. 41, no. 7, pp. 873-888, 2010, doi: 10.1080/0020739X.2010.486448.

[2] M. Camacho-Machín and C. Guerrero-Ortiz, "Identifying and exploring relationships between contextual situations and ordinary differential equations," Int. J. Math. Educ. Sci. Technol., vol. 46, no. 8, pp. 1077-1095, 2015, doi: 10.1080/0020739X.2015.1025877.

[3] M. Lutter, J. Peters, and D. Hochschulstr, "Differential Equations as a Model Prior for Deep Learning and its Applications in Robotics," in ICLR 2020 DeepDiffEq Workshop Differential, 2020, pp. 1-5.

[4] Z. Nuraeni, "Aplikasi Persamaan Diferensial Dalam Estimasi Jumlah Populasi," Delta J. Ilm. Pendidik. Mat., vol. 5, no. 1, p. 9, 2017, doi: 10.31941/delta.v5i1.384.

[5] Nurdeni, W. Lestari, and Seruni, "laju pertumbuhan bakteri s. aerous melalui pendekatan persamaan diferensial," E-Jurnal Mat., vol. 6, no. 3, pp. 183-187, 2017, doi: 10.24843/MTK.2017.v06.i03.p164.

[6] E. Lozada, C. Guerrero-Ortiz, A. Coronel, and R. Medina, "Classroom methodologies for teaching and learning ordinary differential equations: A systemic literature review and bibliometric analysis," Mathematics, vol. 9, no. 7, 2021, doi: 10.3390/math9070745.

[7] J. A. Czocher, "How can emphasizing mathematical modeling principles benefit students in a traditionally taught differential equations course?," J. Math. Behav., vol. 45, pp. 78-94, 2017, doi: 10.1016/j.jmathb.2016.10.006.

[8] R. Jayanti, "Pembelajaran Menggunakan Teknik Probing Prompting Berbantuan Edmodo Blended Learning Pada Materi Persamaan Diferensial Matematis Mahasiswa Di Universitas Pgri Palembang," J. Chem. Inf. Model., vol. 53, no. 9, pp. 1689-1699, 2018.

[9] D. G. Mallet and S. W. McCue, "Constructive development of the solutions of linear equations in introductory ordinary differential equations," Int. J. Math. Educ. Sci. Technol., vol. 40, no. 5, pp. 587-595, 2009, doi: 10.1080/00207390902759626.

[10] L. B. Santos, P. H. F. Xavier, J. V. C. Santos, and R. R. Sampaio, "Teaching of ordinary differential 
equations using the assumptions of the PBL method," Int. J. Eng. Pedagog., vol. 10, no. 3, pp. 7-20, 2020, doi: 10.3991/IJEP.V10I3.12015.

[11] J. A. Gutiérrez and R. R. Gallegos, "Theoretical and methodological proposal on the development of critical thinking through mathematical modeling in the training of engineers," in $A C M$ International Conference Proceeding Series, 2019, pp. 941-948, doi: 10.1145/3362789.3362828.

[12] S. Nursolekah and Suparman, "Design of mathematics learning module based on problem based learning to improve critical thinking ability students," Int. J. Sci. Technol. Res., vol. 8, no. 12, pp. 2608-2616, 2019.

[13] C. P. Dwyer, M. J. Hogan, and I. Stewart, "An integrated critical thinking framework for the $21 \mathrm{st}$ century," Think. Ski. Creat., vol. 12, pp. 43-52, 2014, doi: 10.1016/j.tsc.2013.12.004.

[14] A. Adinda and Hamka, "Critical Thinking Skills of Students From the Aspect of Strategy and Tactics in Solving Mathematics," Int. J. Insights Math. Teach., vol. 02, no. 1, pp. 47-56, 2019.

[15] S. Maričić and K. Špijunović, "Developing Critical Thinking in Elementary Mathematics Education through a Suitable Selection of Content and Overall Student Performance," Procedia - Soc. Behav. Sci., vol. 180, no. November 2014, pp. 653-659, 2015, doi: 10.1016/j.sbspro.2015.02.174.

[16] P. a. Facione, Critical Thinking: What It Is and Why It Counts, no. ISBN 13: 978-1-891557-07-1. 2011.

[17] T. A. Angelo and J. L. Cooper, "Beginning the dialogue: thoughts on promoting Classroom Assessment for Critical Thinking Cooperative Learning and Critical Thinking," Teach. Psychol., vol. 22, no. 1, 1995.

[18] S. Y. Seventika, Y. L. Sukestiyarno, and S. Mariani, "Critical thinking analysis based on Facione (2015) - Angelo (1995) logical mathematics material of vocational high school (VHS)," J. Phys. Conf. Ser., vol. 983, no. 1, 2018, doi: 10.1088/1742-6596/983/1/012067.

[19] W. E. Boyce and R. C. Prima, Elementary Differential Equations and Boundary Value Problems, 10th ed. New Jersey: John Wiley \& Sons, Inc, 2012.

[20] F. Sholihah, S. Inganah, and M. M. Effendi, "Analysis of Critical Thinking Skills By Homeschooling'S Students in Solving Mathematical Problem," Math. Educ. J., vol. 1, no. 2, p. 41, 2017, doi: 10.22219/mej.v1i2.4628.

[21] K. C. Moore and M. P. Carlson, "Students' images of problem contexts when solving applied problems," J. Math. Behav., vol. 31, no. 1, pp. 48-59, 2012, doi: 10.1016/j.jmathb.2011.09.001.

[22] L. M. Almeida and L. A. Kato, "Different approaches to mathematical modelling: Deduction of models and student's actions," Int. Electron. J. Math. Educ., vol. 9, no. 1-2, pp. 3-11, 2014.

[23] M. Karakoc, "The Significance of Critical Thinking Ability in Terms of Education," Int. J. Humanit. Soc. Sci., vol. 6, no. 7, pp. 81-84, 2016, [Online]. Available: www.ijhssnet.com\%0AThe.

[24] S. ŽivkoviL, "A Model of Critical Thinking as an Important Attribute for Success in the 21st Century," Procedia - Soc. Behav. Sci., vol. 232, no. April, pp. 102-108, 2016, doi: 10.1016/j.sbspro.2016.10.034. 